\title{
Critical specific stream power in gravel-bed rivers
}

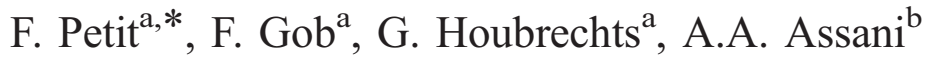 \\ ${ }^{a}$ Department of Geography, University of Liège, Allée du 6 août, 2 (Bât. B11), Sart Tilman, B-4000 Liège, Belgium \\ ${ }^{\mathrm{b}}$ Section de Géographie, Université du Québec à Trois-Rivière, Pavillon Léon-Provencher, 3351, Boulevard des Forges, \\ Trois-Rivières (Québec), Canada G9A $5 H 7$
}

Received 5 April 2004; received in revised form 17 December 2004; accepted 20 December 2004

Available online 1 February 2005

\begin{abstract}
Experiments with marked pebbles were carried out on different sized rivers of the Belgian Ardenne (catchment areas varying from less than $1 \mathrm{~km}^{2}$ to $2700 \mathrm{~km}^{2}$ ). Specific stream power required to cause bedload movement was evaluated and critical values were obtained. Three types of relationship between critical specific stream power $\left(\omega_{0}\right)$ and grain size $(D)$ were established. The values for $\omega_{0}$ in the largest river (the Ourthe) were the lowest and were close to the values obtained for mountainous rivers carrying large boulders. In medium sized rivers (catchment area between 40 and $500 \mathrm{~km}^{2}$ ), the critical unit stream power was higher. It is likely that it is due to the bedform's greater resistance. This resistance would use up some of the energy that can cause movement and transport of bedload. The amount of resistance of the bedform can be expressed as bedform shear stress $\left(\tau^{\prime \prime}\right)$, determined by the relationship between grain shear stress ( $\tau^{\prime}$ — that determines movement and transport of the bedload) and the total shear stress $(\tau)$. This ratio varies between 0.4 and 0.5 in the medium sized rivers, compared to 0.7 in the Ourthe. In headwater streams (less than $20 \mathrm{~km}^{2}$ ), there is greater loss of energy due to bedform resistance $\left(\tau^{\prime} / \tau<0.3\right)$. Critical specific stream power is higher in this third type of river than in the other two.
\end{abstract}

(C) 2005 Elsevier B.V. All rights reserved.

Keywords: Specific stream power; Gravel bed river; Sediment transport; Tracer pebbles

\section{Introduction}

Among the criteria for bedload mobilisation, the critical erosion velocity introduced by Hjulström (1935) is the oldest and was the most widely used in the past. Nowadays, using shear stress has become

\footnotetext{
* Corresponding author.

E-mail address: Francois.Petit@ulg.ac.be (F. Petit).
}

widespread in geomorphology. This has especially been the case since critical shear stress values were proposed for gravel bedload, taking into account (thanks to Shields' dimensionless criterion) protrusion effect and imbrication (Andrews, 1983). Besides, using shear stress allows estimations of bedload transport to be made by means of, for instance, the Meyer-Peter equation. However, in estimating bedload transport, it is generally acknowledged that different approaches should be used so 
that the results can be compared. Bagnold (1977) initially introduced the notion of specific stream power in order to evaluate bedload transport. Since then it has found other fields of application, especially with a view to understanding river activity and in particular regarding channel patterns and meander dynamics (Ferguson, 1981; Bravard, 1991) or the possible reaction and adaptation of rivers following human intervention (Brookes, 1988). Furthermore, specific stream power is widely used as a factor to distinguish riverbeds, notably when braiding has taken place (Van den Berg, 1995). More recently, the distance travelled by the bedload once it has been mobilised has been linked to excess specific stream power in relation to critical specific stream power (Hassan et al., 1992; Gintz et al., 1996). However, the major problem remains in determining a relation that links critical specific stream power to the size of the mobilised material. Bagnold proposed a relation, which is quite complex for practical application. Meanwhile two other relations exist but only for rivers with very coarse bedload (Costa, 1983; Williams, 1983).

Compared to shear stress, specific stream power has the advantage of being easy to determine. It is a simple function of slope, discharge and width which are quite easy to calculate even after a flood event. For shear stress, on the other hand, one needs to know the depth of flow which may be difficult to obtain, particularly afterwards. However, specific stream power does not take into account the role of bedforms (hiding and protrusion effects, pool and riffle sequences) and it is therefore a more basic indicator of river dynamics.

\section{Summary of equations}

Specific stream power, which represents the amount of work that a river may do, is presented in the following form:

$\omega=(\rho g Q S) / w$

with $Q$ as the discharge ( in $\mathrm{m}^{3} \mathrm{~s}^{-1}$ ), $w$ the width of the water surface (in $\mathrm{m}$ ) and $S$ the longitudinal slope (in $\mathrm{m} \mathrm{m}^{-1}$ ), $\rho$ the fluid density (in $\mathrm{kg} \mathrm{m}^{-3}$ ) and $g$ the acceleration due to gravity (in $\mathrm{m} \mathrm{s}^{-2}$ ). In order to allow comparisons between different rivers, the bankfull discharge is generally taken, in which case $w$ is the width between the banks at the level of overflow. For rivers with braided channels, where it is difficult to define the bankfull discharge, the value of the 1.5 year flood is generally taken. This is quite close to the bankfull discharge recurrence interval, even though slight differences may have to be introduced according to the nature of the bedload and the supply mode of the rivers (Petit and Pauquet, 1997).

Furthermore, $S$ is theoretically taken to be the slope of the line of energy or, if this is not possible, as the slope of the water surface. However, the stream power value should be considered as a basic indicator, easy to use in the absence of precise data. In this way, on long sections of rivers, $S$ may be considered to be the longitudinal slope of the bed or even the alluvial plain.

By transformation, specific stream power may be expressed as the following:

$\omega=\tau u$

with $\tau$ as the total shear stress averaged over the width of the river expressed in $\mathrm{N} \mathrm{m}^{-2}$ and $u$ the crosssection average speed of the current expressed in $\mathrm{m}$ $\mathrm{s}^{-1}$. It should be remembered that the total shear stress is in reality the sum of two components: (i) the shear stress due to the resistance of the particles (grain shear stress $\tau^{\prime}$ ), the only one that should be considered in bedload mobilisation and transport and (ii) an additional shear stress due to the resistance of the form of the river bed (bedform shear stress $\tau^{\prime \prime}$ ). As we shall see, it is advisable to take account of this distinction, even when specific stream powers are used.

Bagnold (1980) proposed an equation that allows the critical specific stream power $\left(\omega_{0}\right)$ at which sediments begin to be mobilised to be determined. The initial relation was the following: $\omega_{0}=\tau_{\mathrm{c}} v_{\mathrm{c}}$, where $v_{\mathrm{c}}$ stands for the critical mobilisation speed and $\tau_{\mathrm{c}}$ the critical shear stress when Shields' dimensionless criterion is brought in with a value equal to 0.040 . The latter criterion is expressed as follows:

$\theta_{\mathrm{c}}=\tau_{\mathrm{c}} /\left(\left(\gamma_{\mathrm{s}}-\gamma_{\mathrm{f}}\right) D\right)$

where $\gamma_{\mathrm{s}}$ and $\gamma_{\mathrm{f}}$ represent the specific weight of the particles and the liquid, respectively, and $D$ represents the size of the particles (in $\mathrm{m}$ ). Then, taking particle density to be $2.6 \mathrm{~g} \mathrm{~cm}^{-3}$ and with $\gamma_{\mathrm{s}}$ equal to 26,260 
$\mathrm{N} \mathrm{m}^{-3}$ (Williams, 1983), Bagnold's equation may be expressed in the following form:

$\omega_{0}=0.0971\left(D_{i}\right)^{1.5} \log \left(\frac{1200 d}{D_{\mathrm{i}}}\right)$

where $\omega_{0}$ is the critical unit stream power (in $\mathrm{W} \mathrm{m}^{-2}$ ), $d$ the depth (in m) and $D_{\mathrm{i}}$ the size of the mobilised particles (in $\mathrm{mm}$ ).

Relations linking critical unit stream power to the size of the material alone (without taking depth into consideration) were proposed for steep sloped rivers carrying large boulders (Table 1). From observations carried out in the rivers of Colorado, Costa (1983) highlighted a relation essentially applicable to coarse material (from $50 \mathrm{~mm}$ to over $1000 \mathrm{~mm}$ ):

$\omega_{0}=0.030 D_{\mathrm{i}}^{1.69}$

(where $\omega_{0}$ is expressed in $\mathrm{W} \mathrm{m}^{-2}$ and $D_{\mathrm{i}}$ in $\mathrm{mm}$ ). It was obtained through regression, the straight line passing through a cluster of points. Costa also proposed an envelope curve (relation 6 in Table 1) that passes beneath the points while maintaining a slope parallel to the straight line obtained by regression. The same year, Williams (1983), using a series of observations published in the literature, proposed a relation ( 7 in Table 1) that is rather close to Costa's (for clasts between 10 and $1500 \mathrm{~mm}$ ). Furthermore, two lichenometric studies in the Mediterranean region have allowed relations for streams carrying clasts larger than $2 \mathrm{~m}$ (relations 8 and 9 in Table 1) to be established. Jacob (2003) highlighted a relation for rivers with mobilised material ranging from $700 \mathrm{~mm}$ to $2300 \mathrm{~mm}$ and Gob et al. (2003) worked in a river transporting clasts between 900 and $2000 \mathrm{~mm}$. In these last two relations the largest mobilised boulder size was considered rather than the $D_{50}$ of the bedload, as is generally the case.
These relations give quite similar results. However, they cannot be applied generally. Reid and Frostick (1985) observed in a modest sized river in Southern England $\left(Q_{\mathrm{b}}=19.6 \mathrm{~m}^{3} \mathrm{~s}^{-1}\right)$ that specific stream power must reach $35-40 \mathrm{~W} \mathrm{~m}^{-2}$ to destabilise a paving made of $22 \mathrm{~mm}$ elements. Furthermore, Assani and Petit (2004) find values to the same order as these authors in a river of the Ardenne. The specific stream power must effectively reach $26 \mathrm{~W} \mathrm{~m}^{-2}$ to mobilise elements where the $D_{50}=28 \mathrm{~mm}$. Lastly, Blizard and Wohl (1998) related specific stream power to the $D_{84}$ which was established using a bedload sampler. As these authors emphasise, the relations are not very revealing, but all the same, we may point out the following values: $\omega=10 \mathrm{~W} \mathrm{~m}^{-2}$ for $D_{84}=5 \mathrm{~mm}, \omega=20 \mathrm{~W} \mathrm{~m}^{-2}$ for $D_{84}=13 \mathrm{~mm}$ and $\omega=25 \mathrm{~W} \mathrm{~m}^{-2}$ for $D_{84}=16 \mathrm{~mm}$. It should be noted that these measurements were carried out in a headwater stream (area of less than $10 \mathrm{~km}^{2}$ ), characterised by a steep gradient, a step-pool system and the formation of numerous log-jams - in other words in systems with significant energy dissipation due to the resistance of the features and considerable roughness.

The values presented above differ clearly from those obtained from the relations applicable to coarse material (Table 1). It therefore seems useful to refine the critical specific stream power values for modest sized rivers with a medium slope and characterised by an intermediate sized gravely bedload.

\section{Methodology and characteristics of the rivers studied}

The rivers studied, situated for the most part in the Ardenne, all have a gravel bedload and quite a marked slope, varying from $5 \%$ for headwater streams to less than $0.2 \%$ for larger rivers (Table 2). The discharge regime is relatively variable because these rivers are

Table 1

Equations from the literature $\omega_{0}=a D_{\mathrm{i}}^{\mathrm{b}}$ with $\omega_{0}$ unit stream power $\left(\mathrm{W} \mathrm{m}^{-2}\right)$ and $D_{\mathrm{i}}$ mobilised material size (mm)

\begin{tabular}{llllll}
\hline River & Relation & $a$ & $\mathrm{~b}$ & Size range & Reference \\
\hline Rivers of Colorado & $(5)$ & 0.030 & 1.69 & $50-1000$ & Costa (1983) \\
Rivers of Colorado (envelope curve) & $(6)$ & 0.090 & 1.69 & $50-1000$ & Costa (1983) \\
Several rivers from literature & $(7)$ & 0.079 & 1.30 & $10-1500$ & Williams (1983) \\
Chassezac (France) & $(8)$ & 0.025 & 1.647 & $700-2300$ & Jacob (2003) \\
Figarella (Corsica - France) & $(9)$ & 0.0253 & 1.62 & $900-2000$ & Gob et al. (2003) \\
\hline
\end{tabular}


Table 2

River characteristics

\begin{tabular}{|c|c|c|c|c|}
\hline River & $\begin{array}{l}\text { Catchme } \\
\text { area }(\mathrm{kn}\end{array}$ & $\begin{array}{l}\text { Slope } \\
\left(\mathrm{m} \mathrm{m}^{-1}\right.\end{array}$ & $\begin{array}{l}\omega^{\mathrm{b}} \\
\left(\mathrm{W} \mathrm{m} \mathrm{m}^{-2}\right)\end{array}$ & Reference \\
\hline $\begin{array}{l}\mathrm{Ru} \text { de } \\
\text { Waidages }\end{array}$ & 0.3 & 0.046 & $25^{\mathrm{c}}$ & Assani (1991) \\
\hline $\begin{array}{l}\text { Ruisseau } \\
\text { de la Mer }\end{array}$ & 1.4 & 0.071 & 51 & Mercenier (1973) \\
\hline $\begin{array}{l}\text { Ruisseau } \\
\text { de Wavelinse }\end{array}$ & 4.3 & 0.024 & 18 & Dave (1975) \\
\hline $\begin{array}{l}\text { Ruisseau } \\
\text { de Belleva }\end{array}$ & 12.5 & 0.049 & 129 & Mercenier (1973) \\
\hline Rulles & 16.2 & 0.012 & 17 & Petit (1987) \\
\hline Magne & 41.8 & 0.016 & - & Pironet (1995) \\
\hline Berwinne & 118 & 0.0039 & 53 & Parotte (1991) \\
\hline Warche & 118 & 0.0042 & 42 & Assani (1997) \\
\hline Hoëgne & 219 & 0.017 & 160 & Deroanne (1995) \\
\hline Mehaigne & 354 & 0.0021 & 41 & Perpinien (1998) \\
\hline Lesse (1) & 419 & 0.0028 & 50 & Franchimont (1993) \\
\hline Lhomme & 474 & 0.0022 & 83 & Franchimont (1993) \\
\hline Lesse (2) & 1090 & 0.0020 & 75 & Franchimont (1993) \\
\hline Semois & 1235 & 0.0010 & 23 & Gob et al. (in press) \\
\hline $\begin{array}{l}\text { Ourthe } \\
\text { (lower) }\end{array}$ & 2660 & 0.0025 & 48 & Petit et al. (1996) \\
\hline
\end{tabular}

a Slope calculated from the source to the considered measurement station.

${ }^{\mathrm{b}} \omega$ Calculated for bankfull discharge.

${ }^{\mathrm{c}}$ For 1 year recurrence interval.

developed on an impermeable substratum (lower Devonian quartzite and quartzo-phillite). However, some are developed partly on limestone with a dominant baseflow regime.

Bedload marking by spray painting was undertaken in the different sized rivers and was complemented by observations that had been previously made in different Belgian rivers (Fig. 1). The smallest rivers have a catchment area of just a few square kilometres and the largest covers almost $2700 \mathrm{~km}^{2}$. These observations were related to the dynamic parameters. A comparable methodology was used for each of the rivers, however, some adaptations were required, notably where the rivers' dimensions were concerned. In most rivers, tracer pebbles were painted in situ so as not to disturb the arrangement of the material making up the bed. The characteristics of the bedload size were estimated using the grid-square technique - a method proposed by Kellerhals and Bray (1971) and successfully applied, notably in the Canal de Miribel (Poinsart, 1992). Topographical surveys were made in order to ensure that mobilisation had taken place and that the material had not simply been buried. In rivers of modest dimension, the grid technique proved difficult to apply given that gravel bars were only exposed on limited parts of the bed. The size of the mobilised material was therefore estimated either by measuring the individual elements that had been marked in situ beforehand or by taking samples using sediment traps.

\section{Results and discussion}

The main results are shown in Fig. 2. For the rivers where the relations were highlighted, the equations are shown in Table 3. A number of remarks should be made regarding the manner in which these results were obtained.

- In the Ourthe, seven areas of $1 \mathrm{~m}^{2}$ were marked at three different sites that appeared as large, oblique bars. Mobilisation of all of the marked elements was observed for four different floods. The relationship between the $D_{50}$ mobilised and the specific stream power is poor, thus the envelope curve that passes beneath the points was preferred to the regression curve (Table 2). This weak link is probably due to the fact that the sites are relatively heterogeneous. Furthermore, the stream power value is determined for the whole transverse section, despite the fact that there are rather strong differences within the morphological units. This point had already been raised in an analysis of critical shear stress carried out in the same sites (Petit et al., 1996). As Fig. 3 indicates, the critical specific stream power values highlighted in the Ourthe are around the same as those deduced from the relations of Costa and Williams and differ markedly from Bagnold's equation since, for example, by applying the latter $\omega$ should exceed $60 \mathrm{~W} \mathrm{~m}^{-2}$ to mobilise a $D_{50}=55 \mathrm{~mm}$ at a depth of $2 \mathrm{~m}$.

- Seven sites on the Höegne, spaced out at intervals along a line from the source to the confluence were marked using the grid technique. This river is steep, with a $520 \mathrm{~m}$ change in altitude over a distance of $31 \mathrm{~km}$. Quite a sudden decline in the size of the material may be observed - the $D_{50}$ of the bed material exceeds $200 \mathrm{~mm}$ upstream, yet is no greater than $70 \mathrm{~mm}$ in the downstream part of 


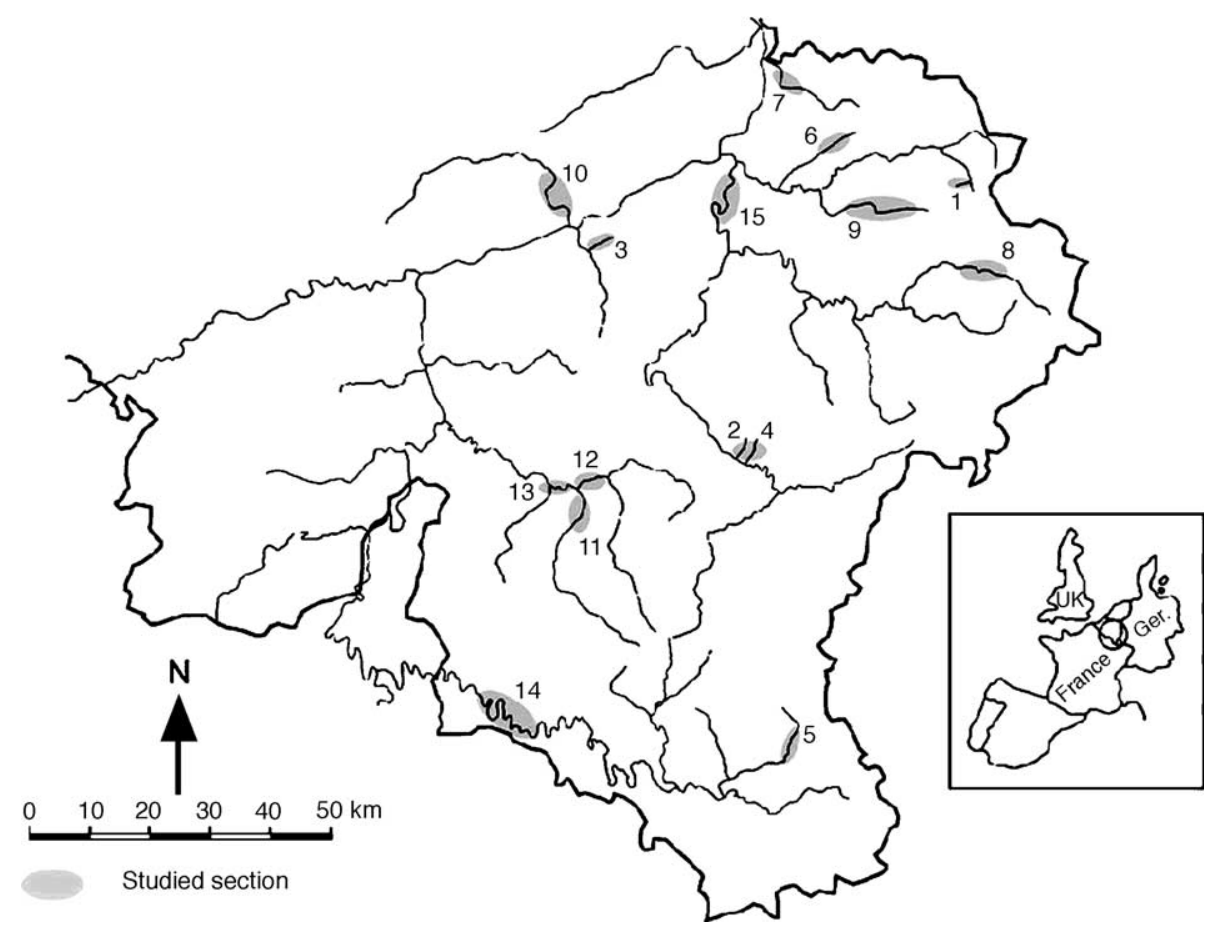

Fig. 1. Location of the studied rivers (see Table 2): (1) Ru de Waidages, (2) Ruisseau de la Mer, (3) Ruisseau de Wavelinse, (4) Ruisseau de Belleva, (5) Rulles, (6) Magne, (7) Berwinne, (8) Warche, (9) Hoëgne, (10) Mehaigne, (11) and (13) Lesse, (12) Lhomme, (14) Semois, (15) Ourthe.

the course (Deroanne and Petit, 1999). Material mobilisation was observed for two floods (representing $0.3 Q_{\mathrm{b}}$ and $0.6 Q_{\mathrm{b}}$, respectively, at the reference station). Stream power was calculated at each of the marked sites according to the specific discharges that had been tested beforehand as well

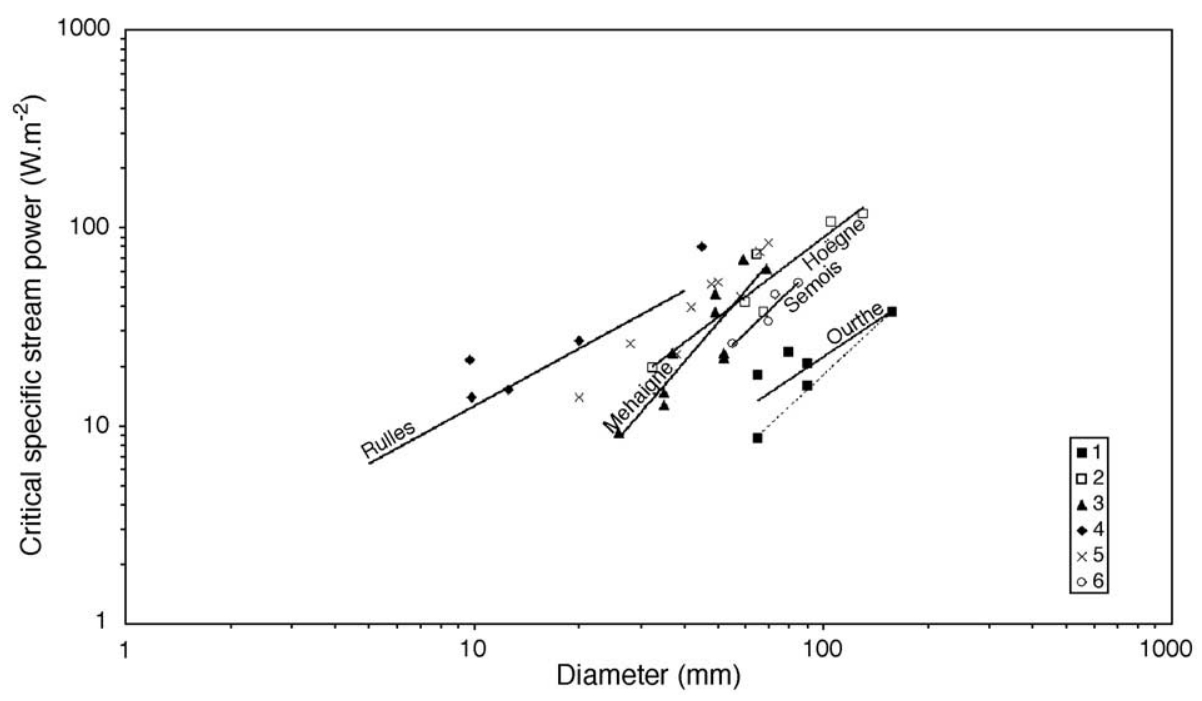

Fig. 2. Relations linking the critical specific stream power and the material size ( $D_{50}$ in $\mathrm{mm}$ ) in several Belgian Rivers: (1) the Ourthe; (2) the Hoëgne; (3) the Mehaigne; (4) headwater streams; (5) intermediate sized rivers; (6) the Semois. 
Table 3

Synthesis of regressions for different rivers

\begin{tabular}{llllllll}
\hline & \multicolumn{1}{l}{$\mathrm{b}$} & $\mathrm{b}$ & $\mathrm{n}$ & $\mathrm{r}$ & $\begin{array}{l}\mathrm{D}_{\mathrm{i}}^{\mathrm{a}} \\
(\mathrm{mm})\end{array}$ & $\begin{array}{l}D_{50}^{\mathrm{b}} \\
(\mathrm{mm})\end{array}$ & Reference \\
\hline Ourthe & 0.098 & 1.176 & 6 & 0.6 & $55-160$ & $56-158$ & $\begin{array}{l}\text { Petit et al. } \\
(1996)\end{array}$ \\
Ourthe & 0.009 & 1.639 & 6 & & $55-160$ & $56-158$ & $\begin{array}{l}\text { Petit et al. } \\
(1996)\end{array}$ \\
Hoëgne & 0.194 & 1.331 & 6 & 0.88 & $32-160$ & $70-230$ & $\begin{array}{l}\text { Deroanne } \\
(1995)\end{array}$ \\
Mehaigne & 0.010 & 2.050 & 10 & 0.78 & $25-70$ & $25-70$ & $\begin{array}{l}\text { Perpinien } \\
(1998)\end{array}$ \\
Semois & 0.030 & 1.679 & 4 & 0.90 & $55-85$ & 70 & $\begin{array}{l}\text { Gob et al. } \\
\text { (in press) }\end{array}$ \\
Rulles & 1.374 & 0.963 & 26 & 0.90 & $5-40$ & $15-60$ & \\
\hline
\end{tabular}

The coefficient shown corresponds with the equation $\omega_{0}=a D_{\mathrm{i}}^{\mathrm{b}}$ with $\omega_{0}$ specific stream power $\left(\mathrm{W} \mathrm{m}^{-2}\right)$ and $D_{\mathrm{i}}$ mobilised material size (mm).

$n=$ number of observations; $r=$ correlation coefficient.

${ }^{\text {a }} D_{50}$ of mobilised sediment.

b $D_{50}$ of the bed material.

c Envelope curve.

as the local slopes and widths. The first and weakest of these floods affected only downstream sites where the area of the catchment is over 80 $\mathrm{km}^{2}$. The record flood also affected upstream sites where the catchment is less than a couple of $\mathrm{km}^{2}$.
- Markings were also made at five different sites of the Mehaigne, again spaced out along an upstream-downstream line, but in this case covering only $15 \mathrm{~km}$ or so (Perpinien, 1998). Mobilisation of material was observed at each site on two occasions (floods to the value of $0.3 Q_{\mathrm{b}}$ and $0.8 Q_{\mathrm{b}}$, respectively, at the reference station); the $D_{50}$ mobilised varies from $25 \mathrm{~mm}$ to $70 \mathrm{~mm}$. The relation established is quite close to that highlighted in the Höegne.

- In the Semois (a large incised meandering river of the southern Ardenne characterised by a very flat bed with numerous bedrock outcrops) hundreds of painted pebbles were injected between October 2000 and December 2001. Mobilisation of markings was observed for two different flood events (Gob et al., in press). There is a good relationship between $D_{50}$ mobilised and the specific stream power showing that this river exhibits a high degree of homogeneity.

- The relation determined on the Rulles is based on a detailed analysis of the mobilisation and transport of a large number of individual elements: almost 270 pebbles marked in situ during six different marking campaigns covering floods from the bankfull discharge to a 5-year flood. These

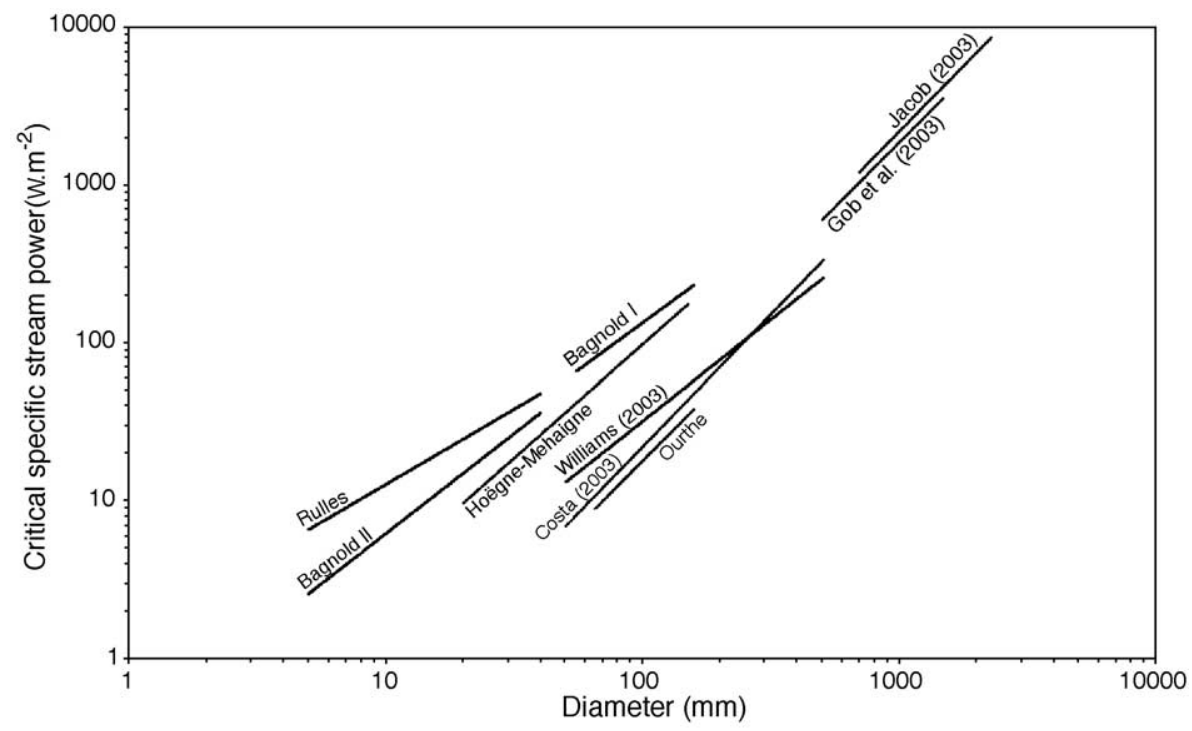

Fig. 3. Relations linking the critical specific stream power and the material size $\left(D_{50}\right.$ in $\left.\mathrm{mm}\right)$ in Belgian gravel bed rivers and mountainous boulder rivers of southern France and Colorado. Bagnold I is the Bagnold's equation (Eq. (4)) with the Ourthe parameters $\left(D_{\mathrm{i}}=55-160 \mathrm{~mm}\right.$ and $d=2 \mathrm{~m})$ and Bagnold II is Eq. (4) with the Rulles parameters $\left(D_{\mathrm{i}}=5-40 \mathrm{~mm}\right.$ and $\left.d=1 \mathrm{~m}\right)$. 
observations were regrouped into 26 classes, each class representing the average diameter of a number of elements (on average 10 or so) mobilised or transported in a specific site, for a given flood. It should be noted from the outset that noticeable differences were not remarked between the values for mobilisation and transport, indicating that there is not a paving effect and that imbrication phenomena are not very developed. The stream power was calculated for the different profiles where mobilisation or transport of material had taken place. This evaluation could be carried out at each profile as the shear stress and the average speed of the current had been measured at each one for the range of mobilising discharges (Petit, 1987).

It should be pointed out, first of all, that the relation established in the Rulles is based on points principally between 5 and $40 \mathrm{~mm}$ (only a small number of points have greater diameters) while in the other relations, the size of the mobilised elements is clearly greater. But, regardless of this, the relation of the Rulles appears to be very different from those highlighted in the other rivers. Indeed, for the same diameter, the critical specific stream power is systematically higher. This may be explained by the fact that this relationship was established in a river of modest dimensions, characterised by marked meandering, an alternation of riffles and pools in quick succession and by vast counter-current zones. A large part of the river's energy is used up to overcome the resistance of bedforms. This is underlined by the $\tau^{\prime} / \tau$ ratio, which is very low in the Rulles ( 0.15 to 0.3 for the bankfull discharge Table 4), implying that a large part of the total shear stress is used by the bedform shear stress $\left(\tau^{\prime \prime}\right)$, which limits the grain shear stress $\left(\tau^{\prime}\right)$ and therefore the energy available for mobilising and transporting the bedload (Petit, 1990). In the Mehaigne, the $\tau^{\prime} / \tau$ ratio calculated in different marking sites for mobilising floods, is higher (0.45). The same is true of the Höegne River, where it ranges from 0.1 to 0.50 according to the position in relation to the source (Deroanne, 1995). In the Ourthe this ratio is from 0.65 to 0.7 for the bankfull discharge. This leads us to think that while total roughness and therefore loss of energy due to the bedforms declines, critical
Table 4

Total shear stress and $\tau^{\prime} / \tau$ ratios of rivers

\begin{tabular}{llll}
\hline & $\tau\left(\mathrm{N} \mathrm{m}^{-2}\right)$ & $\tau^{\prime} / \tau$ & Discharge $^{\mathrm{a}}$ \\
\hline Ru de Waidages & & & \\
$\quad 1$ & 44 & 0.05 & $Q_{1 \mathrm{br}}$ \\
2 & 23 & 0.38 & $Q_{1 \mathrm{br}}$ \\
Rulles & $12-20$ & $0.15-0.3$ & $Q_{\mathrm{b}}$ \\
Berwinne & 25 & $0.3-0.5$ & $Q_{\mathrm{b}}$ \\
Warche & 22 & $0.77^{\mathrm{c}}$ & $0.7 Q_{\mathrm{b}}$ \\
Hoëgne & $20-170$ & $0.10-0.50$ & $0.2 Q_{\mathrm{b}}$ \\
Mehaigne & $20-50$ & 0.45 & $0.7 Q_{\mathrm{b}}$ \\
Lesse & $37-40$ & $0.47-0.65$ & $\sim 0.8 Q_{\mathrm{b}}$ \\
Lhomme & 32 & 0.63 & $0.7 Q_{\mathrm{b}}$ \\
Semois & 24 & 0.66 & $Q_{\mathrm{b}}$ \\
Ourthe (lower) & 30 & $0.65-0.7$ & $0.4 Q_{\mathrm{b}}$ \\
\hline
\end{tabular}

1 system with log-jams; 2 system without log-jam.

${ }^{\text {a }}$ Discharge in relation to bankfull.

b 1 year recurrence interval.

c Very sharp decrease of bedform roughness because of dam releases (Assani and Petit, 2004).

specific stream power, for the same diameter, also declines.

However, it is also possible that another aspect could come into play: the hiding or the protrusion effects that may be expressed by the $\left(D_{\mathrm{i}} / D_{50}\right)$ ratio, where $D_{\mathrm{i}}$ is the mobilised material and $D_{50}$ the bed material (Fergusson, oral comm.). This may be associated with the Shields criterion through Andrews (1983) equation. However, integrating this concept into the critical specific stream power is problematic because it requires field measurements that make specific stream power much more complicated when its aim is to provide an easy to use descriptive indicator. Furthermore, observations show that the $D_{\mathrm{i}} /$ $D_{50}$ ratios (see Tables 3 and 5) do not change in relation to the size of river catchment and they are relatively close to 1 . The mobilised material is mainly painted pebbles in situ (directly in the river bed) with in most cases all of the material have been mobilised.

The critical specific stream power values highlighted in more selective studies support this interpretation. Indeed, in these results, two categories of rivers should be distinguished: the first are rivers situated in headwater streams and the second have a much greater size (Table 2). As Fig. 2 indicates, the critical specific stream powers observed in the headwater streams are high and around the same as those highlighted in the Rulles. Some remarks should be made with regard to these studies (Table 5). Experi- 
Table 5

Relation linking mobilised sediment and specific stream power in headwater streams and intermediate sized rivers

\begin{tabular}{|c|c|c|c|c|c|}
\hline & $D_{\mathrm{i}}(\mathrm{mm})$ & $D_{50}(\mathrm{~mm})$ & $\omega_{0}\left(\mathrm{~W} \mathrm{~m}^{-2}\right)$ & Marking technique & Reference \\
\hline \multicolumn{6}{|l|}{ Headwater streams } \\
\hline \multicolumn{6}{|l|}{ Ru de Waidages } \\
\hline 1 & 9.7 & 22 & 21.5 & Marked pebbles & Assani (1991) \\
\hline 2 & 12.5 & 22 & 15.3 & Marked pebbles & Assani (1991) \\
\hline Ruisseau de la Mer & 20 & - & 27 & Sediment trap & Mercenier (1973) \\
\hline Ruisseau de Belleva & 45 & - & 80.4 & Marked pebbles & Mercenier (1973) \\
\hline Ruisseau de Wavelinse & 9.8 & - & 14 & Sediment trap & Dave (1975) \\
\hline \multicolumn{6}{|l|}{ Intermediate sized rivers } \\
\hline Warche & 28 & 116 & 26 & Marked pebbles (in situ) & Assani (1997) \\
\hline Magne & 70 & - & 84 & Marked pebbles (in situ) & Pironet (1995) \\
\hline \multirow[t]{3}{*}{ Berwinne } & 38 & 42 & 23 & Marked pebbles & Parotte (1991) \\
\hline & 50 & 42 & 52.9 & Marked pebbles (in situ) & Mols (or. com.) \\
\hline & 42 & 42 & 39 & Marked pebbles (in situ) & Mols (or. com.) \\
\hline Lhomme & 58 & 58 & 45 & Marked pebbles (in situ) & Franchimont (1993) \\
\hline \multirow{3}{*}{ Lesse } & 20 & 48 & 14 & Marked pebbles (in situ) & Franchimont (1993) \\
\hline & 48 & 48 & 52 & Marked pebbles (in situ) & Franchimont (1993) \\
\hline & 66 & 66 & 76 & Marked pebbles (in situ) & Franchimont (1993) \\
\hline
\end{tabular}

1 system with log-jams; 2 system without log-jam; $D_{\mathrm{i}}$ mobilised material $(\mathrm{mm}) ; D_{50}$ of the bed material; $\omega_{0}$ specific stream power $\left(\mathrm{W} \mathrm{m}^{-2}\right)$.

ments were undertaken by Assani (1991) in the Ru des Waidages; this order 2 thalweg is actually like a drain with numerous log-jams. The critical stream power was estimated from the movement of 60 or so marked stones. Then, the log-jams having been destroyed, the river bed was left to regenerate and a second marking campaign was carried out in order to estimate the critical stream power in a system where the roughness was clearly reduced. The $\tau^{\prime} / \tau$ ratio hardly exceeds 0.05 in the system with log-jams and reaches 0.38 when the blockages have been removed (Assani and Petit, 1995). This shows that the energy losses due to the resistance of the bedforms are considerable and justify higher critical specific stream powers. The rivers studied by Mercenier (1973) and by Dave (1975) are also characterised by numerous vegetation log-jams and indeed bedrock outcrops. These elements contribute to increased roughness and therefore increased energy loss due to the resistance of the forms. The stream powers deduced from the measurements made by these authors are similar to the relation highlighted in the Rulles.

The critical mobilisation threshold observed in the intermediate sized rivers is quite close to the relations highlighted in the Höegne and the Mehaigne. In these rivers, the energy losses linked to the resistance of the various forms remain high compared to the Ourthe, but are lower than in the headwater streams. In this way, in the Berwinne, the ratio $\tau^{\prime} / \tau$ ranges from 0.3 to 0.5 for the bankfull discharge (Parotte, 1991); in the Lhomme and the Lesse (larger rivers with catchments reaching $500 \mathrm{~km}^{2}$ before their confluence) this ratio is to the order of 0.45 to 0.6 (Franchimont, 1993). Observations were also made on the Soor River by Bastin et al. (1972), a boulder-bed river with steep slopes $\left(0.03 \mathrm{~m} \mathrm{~m}^{-1}\right)$ and a catchment area of about 20 $\mathrm{km}^{2}$. Paint marks were made on several blocks showing that the 1969 flood $\left(810 \mathrm{~W} \mathrm{~m}^{-2}\right)$ was able to move a block of $1 \mathrm{~m}$ of intermediate axis (Pissart oral Comm.). This observation (not on Fig. 1) corresponds quite well with Costa's relation and makes a link between Belgian gravel bed rivers and mountainous boulder rivers in southern France and Colorado (Fig. 3).

Given the rather weak dispersion of points that appear in Fig. 2, the values determined in intermediate-sized rivers were integrated into the results obtained in the Höegne and the Mehaigne in order to fit a single relation (shown in Fig. 3). This may be presented as follows:

$\omega_{0}=0.130 D_{\mathrm{i}}^{1.438}$

where $\omega_{0}$ is expressed in $\mathrm{W} \mathrm{m}^{-2}$ and $D_{\mathrm{i}}$ in $\mathrm{mm}(n=23$, $r=0.879$ ), for a range of bedload whose diameter is 
between 20 and $150 \mathrm{~mm}$ inclusive, in rivers whose catchment area varies from $40-500 \mathrm{~km}^{2}$.

\section{Conclusions}

Three types of relations linking critical specific stream power $\left(\omega_{0}\right)$ to the size of mobilised elements $\left(D_{\mathrm{i}}\right)$ were highlighted. For the largest river (the Ourthe), the $\omega_{0}$ values are the smallest. In rivers of intermediate dimensions (catchment of between 40 and $500 \mathrm{~km}^{2}$ ), the critical specific stream powers are higher. We suggest that this is due to greater bedform, resistance that uses up a significant amount of energy to the detriment of that available to mobilise and transport the bedload. The extent of the resistance of the bedforms is generally considered as bedform shear stress $\left(\tau^{\prime \prime}\right)$. In such a way, the relationship between the grain shear stress $\left(\tau^{\prime}\right.$ - the only one involved in the mobilisation and the transport of bedload) and the total shear stress $(\tau)$ may be used as an indicator of this energy loss due the resistance of the bedforms. This ratio varies between 0.4 and 0.5 for rivers of intermediate dimension, while it reaches 0.7 in the Ourthe. In headwater streams (area less than $20 \mathrm{~km}^{2}$ ), where energy losses due to the resistance of the bedforms are even greater $\left(\tau^{\prime} / \tau<0.3\right)$, the critical specific stream power is higher than in the other two types mentioned. Finally, as is common practice with regard to Shields' criterion, a distinction should be made between "brute critical specific stream power" $\left(\omega_{0}\right.$ taking total shear stress into account) and a critical specific stream power specific to the grains $\left(\omega^{\prime}{ }_{0}\right)$. This risks, however, restricting the field of practical application of specific stream power, given the additional information that using this implies.

\section{Acknowledgments}

Both F. Gob and G. Houbrechts were supported by grants offered by the "Fonds pour la formation à la Recherche dans l'Industrie et dans l'Agriculture". The authors would also like to thank reviewers Prof. I. Reid and Prof. R.I. Fergusson for their valuable comments on this paper, the Direction des
Cours d'Eau non navigable, the Voies Hydrauliques and Service d'Etudes Hydrologiques (SETHY) for the data they provided on discharge rates and rivers topography, as well as Natasha Shields for translating.

\section{References}

Andrews, E.D., 1983. Entrainment of gravel naturally sorted riverbed material. Geological Society of American Bulletin 94, $1225-1231$.

Assani, A.A., 1991. Influence des embâcles sur la morphologie et la dynamique d'un drain à charge caillouteuse (Hautes Fagnes, Belgique). Mémoire de Maîtrise en Géologie des Terrains Superficiels. Univ. Liège. 129 pp.

Assani, A.A., 1997. Recherche d'impacts d'une retenue sur le comportement d'une rivière ardennaise (hydrologie, sédimentologie, morphologie et végétation); cas du Barrage de Butchenbach sur la Warche (Belgique). Thèse de Doctorat en Sciences géographiques., Univ. Liège. 482 pp.

Assani, A.A., Petit, F., 1995. Log-jams effect on bed-load mobility from experiments conducted in a small gravel-bed forest ditch. Catena 25, 117-126.

Assani, A.A., Petit, F., 2004. Impact of hydroelectric power releases on the morphology and sedimentology of the bed of the Warche River (Belgium). Earth Surface Processes and Landforms 29, $133-143$.

Bagnold, R.A., 1977. Bedload transport by natural rivers. Water Resources Research 13, 303-312.

Bagnold, R.A., 1980. An empirical correlation of bedload transport rates in flumes and natural rivers. Proceedings of the Royal Society of London, A 372, 453-473.

Bastin, B., Juvigné, E., Pissart, A., Thorez, J., 1972. La Vallée de la Soor (Haute Fagnes): compétence actuelle de la rivière, dépôts glaciaires ou périglaciaires - compte rendu de l'excursion du 3 juillet 1971. Les Congrès et Colloque de L'Université de Liège, vol. 67 , pp. $295-321$.

Blizard, C.R., Wohl, E.E., 1998. Relationships between hydraulic variables and bedload transport in a subalpine channel, Colorado Rocky Mountains, USA. Geomorphology 22, 359-371.

Bravard, J.-P., 1991. La dynamique fluviale à l'épreuve des changements environnementaux: quels enseignements applicables à l'aménagement des rivières? vol.7. La Houille Blanche, pp. 515-521.

Brookes, A., 1988. Channelized Rivers: Perspectives for Environmental Management. Wiley, Chichester. 326 pp.

Costa, J.E., 1983. Paleohydraulic reconstruction of flash-flood peaks from boulder deposits in the Colorado Front range. Geological Society of American Bulletin 94, 986-1004.

Dave, C., 1975. Etude de la dynamique fluviale d'un petit ruisseau de type torrentiel. Mémoire de Licence en Sciences Géographiques. Univ. Liège. 148 pp.

Deroanne, C., 1995. Dynamique fluviale de la Hoëgne. Evaluation longitudinale des caractéristiques sédimentologiques du 
lit et des paramètres de mobilisation de la charge de fond. Mémoire de Licence en Sciences géographiques. Univ. Liège. $155 \mathrm{pp}$.

Deroanne, C., Petit, F., 1999. Longitudinal evaluation of the bed load size and its mobilisation in a gravel bed river. In: Casale, R., Margotini, C. (Eds.), Floods and Landslides, Integrated Risk Assessment. Springer, pp. 335-342.

Ferguson, R.I., 1981. Channel forms and channel changes. In: Lewin, J. (Ed.), British Rivers. G. Allen \& Unwin, London, pp. $90-125$.

Franchimont, C., 1993. Dynamique fluviale de la Lesse: fréquence des inondations, morphométrie des méandres et sédimentologie du lit. Mémoire de licence en Sciences Géographique. Univ. Liège. $121 \mathrm{pp}$.

Gintz, D., Hassan, M.A., Schmidt, K.H., 1996. Frequency and magnitude of bedload transport in a mountain river. Earth Surface Processes and Landforms 21, 433-455.

Gob, F., Petit, G., Bravard, J.-P., Ozer, A., Gob, A., 2003. Lichenometric application to historical and subrecent dynamics and sediment transport of a Corsican stream (Figarella RiverFrance). Quaternary Science Reviews 22, 2111-2124.

Gob, F., Houbrechts, G., Hiver, J.-M., Petit, F., in press. River dredging, channel dynamics and bedload transport in an incised meandering river (The River Semois, Belgium). River Research and Applications.

Hassan, M.A., Church, M., Ashworth, P.J., 1992. Virtual rate and mean distance of travel of individual clasts in gravel bed channels. Earth Surface Processes and Landforms 17, 617-627.

Hjulström, P., 1935. Studies of the morphological activity of rivers as illustrated by the River Fyris. Bulletin of the Geological Institutions of the University of Uppsala 25, $221-527$.

Jacob, N., 2003. Les vallées en gorges de la Cévenne vivaraise, Montagne de sable et château d'eau. Thèse de Doctorat, Univ. Paris IV Sorbonne. 460 pp.

Kellerhals, R., Bray, D.I., 1971. Sampling procedures for coarse fluvial sediment. Journal of the Hydraulics Division ASCE 997 (Hy 8), 1165-1180.
Mercenier, J., 1973. Dynamique fluviale dans un petit bassin du rebord méridional du plateau des Tailles. Mémoire de licence en Sciences géographiques. Univ. Liège. $148 \mathrm{pp}$.

Parotte, V., 1991. Evolution géomorphologique actuelle d'une rivière en relation avec les modifications de son régime hydrologique. La Berwinne à Dalhem (Entre Vesdre et Meuse). Mémoire de Licence en Sciences Géographiques. Univ. Liège. $84 \mathrm{pp}$.

Perpinien, G., 1998. Dynamique fluviale de la Mehaigne: morphométrie, transports en solution et suspension, mobilisation de la charge de fond. Mémoire de Licence en Sciences Géographiques. Univ. Liège. 128 pp.

Petit, F., 1987. The relationship between shear stress and the shaping of the bed of a pebble-load river (la Rulles-Ardenne). Catena 14, 453-468.

Petit, F., 1990. Evaluation of grain shear stress required to initiate movement of particle in natural rivers. Earth Surface Processes and Landforms 15, 135-148.

Petit, F., Pauquet, A., 1997. Bankfull discharge recurrence interval in gravel-bed rivers. Earth Surface Processes and Landforms 22, $685-693$.

Petit, F., Pauquet, A., Pissart, A., 1996. Fréquence et importance du charriage dans des rivières à charge de fond graveleuse. Géomorphologie 2, 3-12.

Pironet, C., 1995. Régime hydrologique, transports de sédiments et dynamique fluviale de la Magne. Mémoire de Licence en Sciences Géographiques. Univ. Liège. 168 pp.

Poinsart, D., 1992. Effets des aménagements fluviaux sur les débits liquides et solides. L'exemple du Rhône dans les plaines de Miribel-Jonage et de Donzère-Mondragon. Thèse de Géographie et Aménagement, Univ. Lyon 3. 501 pp.

Reid, I., Frostick, L.E., 1985. Dynamics of bedload transport in Turkey Brook, a coarse-grained alluvial channel. Earth Surface Processes and Landforms 11, 143-155.

Van den Berg, J.H., 1995. Prediction of alluvial pattern of perennial streams. Geomorphology 12, 259-279.

Williams, G.P., 1983. Paleohydrological methods and some examples from Swedish fluvial environments. Geografiska Annaler 65A, 227-243. 